\title{
ТЕКСТОЛОГІЧНІ АСПЕКТИ ШЕВЧЕНКОЗНАВЧИХ СТУДІЙ ПАВЛА ФИЛИПОВИЧА
}

\author{
Мирослава Гнатюк
}

\author{
Доктор філологічних наук, професор, \\ Кафедра історії української літератури, теорії літератури та літературної творчості, \\ Київський національний університет імені Тараса Шевченка (УКРАЇНА), \\ 01004, Київ, бульвар Тараса Шевченка, 14, \\ e-mail: gnatjuk-m@ukr.
}

\section{РЕФЕРАТ}

Mema. Стаття присвячена дослідженню текстологічних аспектів Шевченкознавчих студій Павла Филиповича. Метою статті $є$ аналіз текстологічних принципів дослідження Шевченківського тексту в науковій практиці письменника і вченого. Дослідницька методика. У роботі використаний системний підхід за допомогою текстологічного, філологічного, джерелознавчого, герменевтичного, рецептивного, психологічного, культурно-історичного, компаративного методів. Результати. Зазначено, що в літературознавчому доробку Павла Филиповича дослідження літературної спадщини Тараса Шевченка посідає головне місце. Вчений ретельно працював над встановленням істинно авторських текстів, очищенням їх від цензурних втручань, розкриттям специфіки творчої лабораторії митця, його світоглядно-естетичних поглядів. Наукова новизна. У роботі вперше досліджено рецепцію Шевченкового тексту з поля зору текстологічних і джерелознавчих студій у науковому дискурсі Павла Филиповича. Проаналізовано новизну його першопрочитань, важливих для встановлення автентичності авторського тексту, глибшого розуміння художньо-естетичних принципів письменника. Практичне значення. Матеріал статті може бути використаний при подальшому вивченні теорії, історії літератури, літературного джерелознавства і текстології.

Ключові слова. Рукопис, автентичний текст, редакція, варіант, творча воля автора, цензура, репресії.

\section{TEXTOLOGICAL ASPECTS OF PAVLO PHYLYPOVYCH'S SHEVCHENKO STUDIOS}

\section{Myroslava Hnatiuk}

\author{
Professor Doctor Habilitatus of Philology, \\ Department of Ukrainian Literature History, Theory of Literature and Literary Art, \\ Taras Shevchenko National University of Kyiv (Ukraine), \\ 01601, Kyiv, 14, Tarasa Shevchenka Boulevard, \\ e-mail: gnatjuk-m@ukr.
}

\begin{abstract}
Aim. The article considerstextological aspects of Pavlo Phylypovych'sShevchenko studies. The aim of the article is to analyze the textological principles of Shevchenko's text research in scientific work of writers and researchers. Methods. The work uses a systematic approach involving textological, philological, source study, hermeneutic, receptive, psychological, cultural and historical, and comparative methods. Results. The article indicated thatresearch of the literary heritage of Taras Shevchenko occupies the main place in the literary studies of Pavlo Phylypovych. The researcher carefully worked on the identification of true author texts, their purification from censorship effects, and revelation of peculiarities of the artist's creative process, his worldview, and aesthetic views. Scientific novelty. In the article, reception of Shevchenko's text was for the first time researched from the perspective of textological and source studies in scientific discourse of Pavlo Phylypovych. The novelty of his first readings, which are important for the identification of the authenticity of the author text and deeper
\end{abstract}


understanding of artistic and aesthetic principles of the artist, was analyzed. Practical meaning. The article can be used for further studies of theory, literature history, literary sources studies, and textology. repression.

Key words: manuscript, authentic text, wording, variant, creative will of the author, censorship,

Літературознавчий доробок Павла Филиповича, як і його поетична спадщина, назавжди вписані у контекст вітчизняної науково-культурної думки. Закінчивши із золотою медаллю в 1910 році знамениту Колегію Павла Галагана, талановитий юнак поступає на юридичний факультет Київського університету Святого Володимира, та невдовзі переводиться на історико-філологічний, де починає займатися дослідницькою працею. Значною мірою цьому сприяє благодатна атмосфера філологічного семінару Володимира Перетца, в роботі якого він бере активну участь. У 1914 році Товариство Нестора-літописця публікує першу наукову доповідь студента, а згодом з'являються його статті, присвячені життю і творчості російського поета Євгена Баратинського. Вже самі назви засвідчують новаторство і пошуковість, джерелознавчо-текстологічне спрямування студій: «Два невідомі вірші Є. А. Баратинського» (1914), «Про академічне видання творів Баратинського» (1915), «Про другий том академічного видання Творів Баратинського» (1916). Досить детальні й грунтовні розсліди закономірно приводять вихованця філологічного семінару до написання вагомої монографії «Життя і творчість Є. А. Баратинського», яка була відзначена золотою медаллю. Залишений при університеті як професорський стипендіат (разом із М. Драй-Хмарою), від 1920 року Павло Филипович працює приват-доцентом, а згодом - від 1922-го і до 1935 року професором цього вишу.

Констатуючи ті позитивні зміни, які відбувалися в царині українського слова на початку 20-их років XX ст., коли воно увійшло в «систему освіти широких трудящих мас», П. Филипович ставить своїм завданням дати відповідь на питання не лише «як?», але i «що?» вивчати. Наступним кроком на означеному колись у семінарі Володимира Перетца шляху він бачить вивчення сучасної літератури. Свою позицію акцептує посиланням на статтю І. Я. Айзенштока «Изучение новой украинской литературы» («Путь просвещения», 1922, № 6), яка розвіювала сумнів акад. В. М. Перетца щодо можливості наукових студій 3 історії літератури XIX віку. Нова стратегія означувалася так: «Вопрос о возможности изучения литературы ближайшего нам времени, как известно, разрешен в положительную сторону: признаю, что можно изучать даже современную нам литературу». «Хронологический момент играет в изучении литературы второстепенную роль, на первом же плане находятся вопросы материала и методов" [5, с. 243]. Із методологічної точки зору вихованці семінару Володимира Перетца були оснащені досконально. Практика роботи з архівними першоджерелами, стародруками, різними редакціями та варіантами, списками не минула даремно, запоручивши успіх праці молодих дослідників. Текст твору, як основний предмет текстології, філологічного знання загалом, його генетика і поетика логічно опинилися в центрі їхньої уваги, що забезпечувало науковим студіям високий рівень фаховості та об'єктивності. Стереоскопічне бачення тексту крізь призму історії його становлення, вияву творчої волі 
автора, художньої специфіки, місця твору в широкому історико-літературному контексті забезпечило надійний підмурівок грунтовним філологічним студіям. Саме така праця дозволяла робити глибокі теоретико-, історико-літературні висновки, продукувати нові концепції, накреслювати перспективні шляхи розвитку літературознавчої науки. Діяльність семінару Володимира Перетца, а згодом й учнів його випускників, засвідчила органічне поєднання теорії i практики, що базувалися на новітніх методах вивчення тексту. Відштовхуючись від дослідження давніх творів, як своєрідного полігону вищої школи, вихованці семінару та їхні підопічні розробляли нові методи аналізу художніх текстів на теренах сучасної літератури, зокрема, із застосуванням формальної методики, текстологічних принципів. За слушним спостереженням Я. Поліщука: «Основу філологічного методу В. Перетц вбачав у ретельному вивченні першоджерел. Він вважав, що сумарні результати такої чорнової роботи мають стати підвалиною для майбутніх досліджень, спроможних досягти вищої мети» [7, с. 64]. Стратегічне мислення Вчителя знайшло своє яскраве ствердження у наукових студіях випускників семінару, де визначальним принципом залишався: «Суворий емпіризм, вимога ерудиції, строгості методу, можливої повноти матеріалу, доказовості положень й чіткості завдань роботи, іiі викладу та висновків» $[1$, с. 21]. Спираючись на ці засади, молоді вчені досягли вагомих результатів у дослідженні літератури нової та новітньої доби. Формуючи власні методологічні пріоритети, вони не забували й про вітчизняну філологічну традицію, зокрема вчення О. Потебні, безцінні уроки роботи з текстом, здобуті в семінарі В. Перетца.

Ефективність такої методики яскраво засвідчили шевченкознавчі студії Павла Филиповича. Досконале володіння теоретичними знаннями, професійним інструментарієм аналізу тексту поставило його в ряд найавторитетніших дослідників творчості Тараса Шевченка пореволюційної доби. Як активний учасник Історично-літературного товариства при ВУАН, секретар створеної 27 лютого 1919 року постійної комісії для видання пам'яток нової української літератури, разом з однодумцями він виношує ідею видання повного зібрання творів Тараса Шевченка. Наполеглива робота у цій сфері розпочинається 3 детального вивчення першоджерел, перегляду фактологічної бази, грунтовного аналізу світоглядно-естетичних засад творчості митця, історико-літературного контексту, критичного переосмислення стереотипних та хибних уявлень про його спадщину (зокрема, костомарівської концепції народності поета; драгоманівських поглядів на «громадську і поетичну цінність творів Шевченка», його нібито малоосвіченість; ідеологічне трактування «класовості» Шевченкового світогляду в монографії А. Річицького «Шевченко в світлі епохи» (1923). Означивши актуальні завдання шевченкознавчих студій, П. Филипович скрушно зауважив: «Ми не маємо ще повного критично перевіреного й коментованого тексту «Кобзаря», не маємо грунтовної, позбавленої поетичних прикрас та легенд біографії, не маємо, нарешті, наукового всебічного аналізу (соціологіч- 
ного ${ }^{1}$, психологічного, формального, історико-порівняльного та ін.) Шевченкової спадщини» [4, с. 7].

Найпершою умовою вирішення цих завдань стала серйозна текстологічна праця, навики якої здобулися в семінарі Володимира Перетца. Розпочалася вона 3 двох невеликих, але дуже суттєвих заміток - «Листи Максимовича до Шевченка» та «Нові рядки Т. Шевченка» (обидві - 1919 р.). Предмет дослідження першої визначала історія «дружби й охолоди» Тараса Шевченка і Михайла Максимовича крізь призму епістолярного тексту. Промовиста назва другої розвідки виявляла iі пошуково-відкривавчий характер, де на основі текстологічного аналізу вносилися суттєві уточнення до основного тексту поезії Тараса Шевченка «Марку Вовчку». Так, на початку розвідки Филипович слушно зауважував: «Кожний рядок з творів великих поетів потрібно зберегти: коли не для читача, то для того, хто буде студіювати твори письменників. Знання варіантів, перших редакцій і т. д. особливу вагу має при досліджуванні процесу творчости. Робота над текстом Шевченка ще майже не починалася, коли не рахувати такого сирого матеріалу, як «Критичний розслід над текстом «Кобзаря» В. Доманицького (Київ, 1907 р.)» [6, с. 58]. Цікава сама історія цієї знахідки. Невідомі раніше рядки поезії «Марку Вовчку» (записані олівцем), збереглися в листі М. Максимовича до Т. Шевченка від 6 жовтня 1859 року. Звіривши ці записи з письмом автографів поета, П. Филипович ствердив їхню ідентичність. На підставі інших подібних прикладів, учений доходить прозірливого висновку: «Це дуже цікаво: поет хапає папір, який трапиться під рукою, і записує те, що підказує фантазія. На цей раз пригодився лист од приятеля. Початкову редакцію другого вірша („Подражаніє Iсаї”, глава 35, дата III. 25. 1895) написано олівцем на офорті роботи Соколова 3 великими поправками (див.: Доманицький. Op. cit. С. 324-325). Олівцем на картоні написано четверту редакцію „Сна” (Доманицький. Op. cit. С. 321). Ці характерні риси малюють нам постать справжнього натхненного поета...» [6, с. 58-59]. Продовженням текстологічних студій стають праці П. Филиповича «Шевченко в зв'язку з його добою» (1925), «Революційна легенда про Шевченка чи дійсність?» (1926), блок статей під умовною назвою «Шевченко й українська література XIX ст.», «Шевченко і російська література XIX ст.», «Свропейські письменники в Шевченковій лектурі» (1926), а також коментарі до видання «Журналу» T. Шевченка в IV томі творів. Акцептуючи тему зв'язків великого поета $з$ його добою, дослідник особливо наголошує на важливості розширення джерельної бази, пошуку нових даних, які допоможуть глибше пізнати життя i творчість митця. Це адресувалося не тільки історикам письменства, а й широкому читачеві, який «цілком спрощено підходить до неї. Він знає основні моменти біографії, головним чином ті, що припадають на арешт і заслання, знає вірші (зібрані в збірникові «Кобзар») і задовольняється цим. «Щоденник» до останнього часу був йому майже невідомий, російські повісті ще трудніше було розшукати, навіть в українських перекладах, малюнки Шевченкові теж не кра-

\footnotetext{
${ }^{1}$ Йшлося про подачу науково достовірних фактів, на відміну від вульгарно-соціологічних схем. (M. Г.).
} 
щу долю мали - багато 3 них ще й не видано, а ті, що зібрані в книзі О. Новицького, не так легко дістати» [6, с. 90]. Саме спираючись на широку джерельну базу, П. Филипович детально висвітлює текстологічну історію легенди про зерна в статті «Революційна легенда про Шевченка чи дійсність?» (1926), яка «у фольклорному побутуванні предметно пояснювала агітацію Т. Шевченка серед селян і причини його арешту в 1859 р.» [2, с. 202]. Різні варіанти й джерела цієї легенди раніше розглядалися Іваном Франком, Василем Щуратом та іншими дослідниками в проекції на конкретні факти біографії Тараса Шевченка. Проте лише Филипович наводить найвірогіднішу версію, підкріпивши свої спостереження мемуарами й фольклорними матеріалами, не врахованими його попередниками. Цікавими є розсліди вченого на теренах російської літератури, зокрема в статтях: «А. Майков про Шевченка» (1923), «Шевченко і декабристи» (1924, доповнений текст вийшов окремою книжкою в 1926 р.), «Український елемент у творах М. Лєскова» (1929), «Шевченко і Плещеєв» (1929), замітці «Невідомий лист Некрасова про Шевченка» (1928). Для цих робіт, як і багатьох інших, характерним є методологічний плюралізм, де активно задіяні текстологічний, формально-поетикальний, джерелознавчий, психологічний, порівняльно-історичний та інші методи дослідження. Власне, така практика є визначальною для літературознавчих праць Павла Филиповича.

Аналізуючи вірш А. Майкова «На белой отмели Каспийского поморья» (назва першого рядка), автор статті звертає увагу не лише на різнобій подачі його датування в різних виданнях - 1859 та 1860 роки, але й досліджує різноваріантність тексту, дійшовши висновку: «і одна, і друга дата можуть тільки підтримати мою думку, що «певец», про якого написав Майков свого вірша - не хто інший, як Шевченко» [6, с. 165]. Своє припущення він логічно обгрунтовує часом повернення українського поета з заслання, його відвідинами Петербурга, де в літературно-мистецьких колах той зустрів дуже теплий прийом. Відомостей про особисте знайомство Шевченка і Майкова немає, але дослідник не відкидає такої можливості. «В усякому разі, - пише він, повернувшися восени 1859 р. $з$ подорожі до Греції (а Шевченко повернувся тоді 3 Києва), Майков міг коли не познайомитися 3 ним, то почути про його життя в засланні, про жорстоке знущання над словом поета... Дуже можливо, що Майков, який перекладав на російську мову білоруські пісні, читав і розумів i твори українського Кобзаря» [6, с. 165]. Проводячи художні паралелі в творчості обох митців, Филипович наголошує на тому, що ця поезія є не тільки виявом співчуття російського поета до Шевченка, а й «дає цікаву деталь для характеристики творчости самого Майкова» [6, с. 165].

У статті «Український елемент у творах М. Лєскова» (1929) дослідник вказує на факт особистого знайомства двох митців, вияв симпатії російського письменника до нашого поета, зауважує на численних ремінісценціях, функціонуванні шевченківських цитат і мотивів у його творах. Детальний аналіз підтвердив текстові запозичення в романі Лєскова «Нікуди» 3 Шевченкової поеми «Сон» та 3 поеми «Гайдамаки» у повісті «Сміх і горе». Відомі рядки «славних прадідів великих правнуки погані» російський автор актуалізував у 
своїй статті «Старовинні психопати», а в оповіданні «Вівцебик» пригадав використання легенди про «маніпуляцію з зернами».

Евристично-текстологічна методика виразно позначилася й на розслідах Павла Филиповича «Невідомий лист Некрасова про Шевченка» (1928) та «Шевченко і Плещеєв» (1929). Закликаючи дослідників пильніше вивчати життя i творчість Шевченка періоду заслання, Филипович звертає особливу увагу на його зв'язки з польськими та російськими політичними засланцями, насамперед - колишнім петрашевцем Олексієм Плещеєвим і діячем польського визвольного руху Броніславом Залєським. Він уважно студіює російські переклади творів українського поета Олексієм Плещеєвим, вказує на можливу зустріч обох ще в Петербурзький період, а також під час заслання в Уральську. В усякому разі, констатує вчений, «Шевченко в листі до Бр. Залєського називає Плещеєва, як постать, відому йому» [6, с. 185]. Аналізуючи переклад Плещеєвим вірша Шевченка «Ляхам» («Ще як були ми козаками»), доходить обгрунтованої думки про знайомство перекладача з цим текстом ще на стадії рукопису, через посередництво Бр. Залєського [6, с. 187]. Упродовж 1858-1861 років О. Плещеєв переклав 9 творів Т. Шевченка й більшість його перекладів опубліковані раніше за оригінал, або одночасно $з$ ним. Серед цих творів «Минають дні, минають ночі», «Сон» («На панщині пшеницю жала»), «Ще як були ми козаками» та ін. Перу О. Плещеєва належить і перший російський переклад поеми «Наймичка» Т. Шевченка $(1860$, ж. «Современник»). Відомий факт листування між обома митцями. На жаль, ці листи не збереглися, за винятком одного послання Т. Шевченка до О. Плещеєва.

Важливе місце серед текстологічних студій Павла Филиповича посідає робота над коментарями до «Журналу» Тараса Шевченка, видрукуваного у складі повного зібрання творів письменника, том четвертий (1927). Загальна редакція, більше чотирьохсот приміток та вступна стаття до тому належали академіку Сергію Єфремову. Цілісний корпус коментарів зайняв 553 сторінки, а сам текст «Журналу» - 187 сторінок. Оглядаючи свою направду подвижницьку працю, С. Сфремов писав: «Я думаю, що коли забудеться до останнього рядка все, що я написав і надрукував, залишиться все ж оце видання Шевченка» $[8$, с. 306]. Високий фаховий рівень цього видання відзначила наукова спільнота, зауваживши лише на дещо розлогих і публіцистичних примітках, а також на «нейтральному» академізмі при висвітленні актуальних тем. Проте, як слушно спостеріг В. Дорошенко: «Затекстовий коментар до IV тому правив на той час за справжню енциклопедію шевченкознавства, з якої в наступні роки щедро черпалися матеріали для багатотомних видань творів Шевченка, універсальних та галузевих енциклопедій. <...> Своєю науковою грунтовністю, документальною доказовістю коментарі до IV тому вигідно відрізнялися від приміток до виданого I. Айзенштоком Шевченкового щоденника (під назвою „Дневник”, 1925), в якому добру половину текстів 348-ми приміток складало цитування (повне чи часткове) листів Шевченка, Б. Залєського, М. Щепкіна, П. Куліша, Я. Кухаренка, численних мемуарних та офіційних матеріалів» [2, с. 205]. Коментарі, які належали Павлу Филиповичу (42 позиції), торкалися найширших сфер літературного життя, включаючи біографічні довідки до кожної 
персоналії, критичну оцінку творів, рецептивні аспекти, бібліографічні відомості. Йшлося про широкий пласт української, російської, західноєвропейської літератур, видатних культурно-громадських діячів, науковців, тощо. Як і попередні розсліди ученого, це незаперечно стверджувало думку, що Тарас Шевченко «був у курсі ідейних напрямів і літературних смаків своєї доби» [3, с. 387], високоосвіченою людиною свого часу.

На жаль, унікальність українських талантів як для репресивного радянського, так і для царського режимів не стала засторогою. Навпаки, завжди сприймалася як найбільша загроза тотальному оболванюванню людей, розправи з інакомислієм. Павла Филиповича арештували 5 вересня 1935 року за сфабрикованими звинуваченнями в приналежності до контрреволюційної націоналістичної організації. Засуджений спочатку на смертне покарання, а потім на десять років ув'язнення у «виправно-трудових таборах 3 конфіскацією майна», Филипович був засланий на Соловки, де перебував у стані глибокої депресії. Намагаючись полегшити долю чоловіка, його дружина - талановита скульпторка Марія Андріївна Михайлюк-Филипович також потрапила в лабета енкаведистів. Від марності зусиль й безвиході в неї стався психологічний злам. 21 березня 1938 року знесилену жінку етапували до виправно-трудового табору «Карлагу НКВД» із десятирічним терміном ув'язнення, де сліди по ній загубилися. 3 листопада 1937 року Павла Филиповича, разом із Миколою Зеровим, Марком Вороним, Павлом Пилипенком та багатьма іншими культурними і громадськими діячами, розстріляли в урочищі Сандармох, «приурочивши» щоденні розстріли безвинних людей 20-ій річниці Жовтневого перевороту. Винесений Павлу Филиповичу вирок було скасовано Військовою Колегією Верховного Суду СРСР 31 березня 1958 року «за відсутністю складу злочину».

\section{ЛІТЕРАТУРА}

1. Чижевський Д. Українське літературне бароко : Вибрані праці з давньої літератури. Київ : Обереги, 2003. 576 с.

2. Дорошенко В. Шевченкіана Павла Филиповича. Филипович П. Шевченкознавчі студіі. Черкаси : Брама; Видавець Вовчок О. Ю., 2002. С. 199-215.

3. Филипович П. Беранже П'єр-Жан. Шевченко Т. Повне зібрання творів. Київ, 1927. T. IV : Щоденні записи («Журнал»). С. 384-387.

4. Филипович П. Від редактора. Шевченківський збірник. Київ, 1924. Т. 1. С. 2-9.

5. Филипович П. П. Літературно-критичні статті / упоряд., авт. передмови і приміт.

С. С. Гречанюк. Київ : Дніпро, 1991. 270 с.

6. Филипович П. Шевченкознавчі студії. Черкаси : Брама; Видавець Вовчок О. Ю., 2002. $220 \mathrm{c}$.

7. Поліщук Я. О. Література як геокультурний проект : монографія. Київ : Академвидав, 2008. $304 \mathrm{c}$.

8. Єфремов С. Щоденники : 1923-1929. Київ : ЗАТ «Газета „Рада”», 1997. 848 с.

\section{REFERENCES}

1. Chyzhevskyi, D. (2003), Ukrainian literature Baroco: Selected works from Ancient literature [Ukrainske literaturne baroko : Vybrani pratsi z davnoi literatury], Oberehy, Kyiv, 576 p. (in Ukrainian).

2. Doroshenko, V. (2002) "Pavlo Phylypovych's Schevhenkiana", Phylypovych P. Studies of Shevchenko ["Shevchenkiana Pavla Fylypovycha", Fylypovych P. Shevchenkoznavchi studii], Brama, Publisher Vovchok O.Yu., Cherkasy, p. 199-215. (in Ukrainian). 
3. Phylypovych, P. (1927), "Béranger Pierre-Jean", Shevchenko T. Complete collection of works. Vol. IV: Daily records ("Journal") [Shevchenko T. Povne zibrannia tvoriv. T. IV: Shchodenni zapysy ("Zhurnal”)], Kyiv, p. 384-387. (in Ukrainian).

4. Phylypovych, P. (1924), "From the editor" ["Vid redaktora"], Shevchenkivskyi zbirnyk, Vol. 1. p. 2-9. (in Ukrainian).

5. Phylypovych, P.P. (1991), Literary and critical articles [Literaturno-krytychni statti], Dnipro, Kyiv, 270 p. (in Ukrainian).

6. Phylypovych, P. (2002), Studies of Shevchenko [Shevchenkoznavchi studii], Brama, Publisher Vovchok O.Yu., Cherkasy, 220 p. (in Ukrainian).

7. Polischuk, Ya.O. (2008), Literature as a geocultural project [Literatura yak heokulturnyi proekt], Akademvydav, Kyiv, 304 p. (in Ukrainian).

8. Yefremov, S. (1997), Diaries: 1923-1929 [Shchodennyky], Paper “Council”, Kyiv, 848 p. (in Ukrainian).

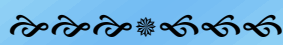

